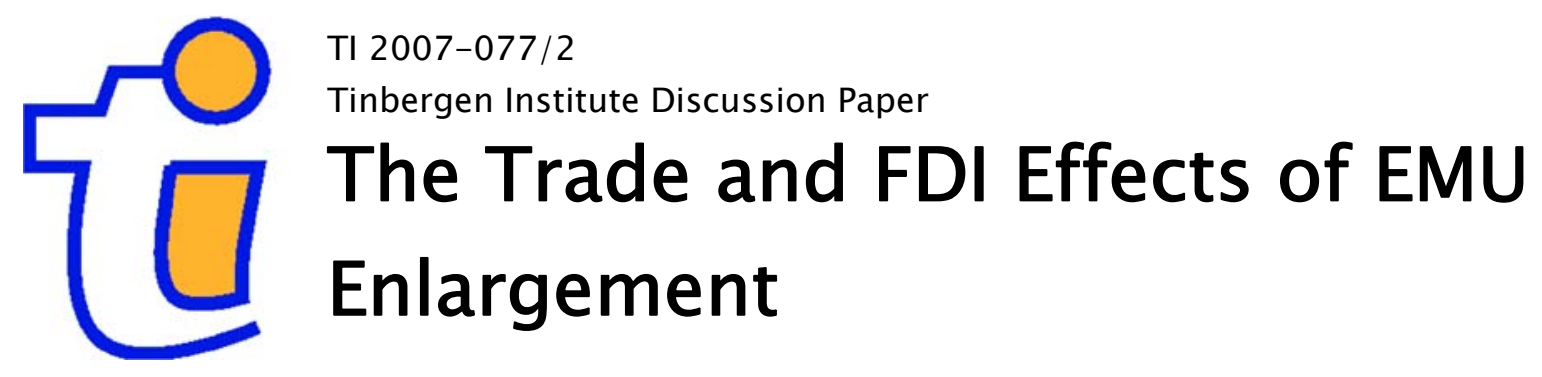

Jelle Brouwerl

Richard Paap ${ }^{1,2,3}$

Jean-Marie Viaene',2,3 


\section{Tinbergen Institute}

The Tinbergen Institute is the institute for economic research of the Erasmus Universiteit Rotterdam, Universiteit van Amsterdam, and Vrije Universiteit Amsterdam.

Tinbergen Institute Amsterdam

Roetersstraat 31

1018 WB Amsterdam

The Netherlands

Tel.: $\quad+31(0) 205513500$

Fax: $\quad+31(0) 205513555$

Tinbergen Institute Rotterdam

Burg. Oudlaan 50

3062 PA Rotterdam

The Netherlands

Tel.: $\quad+31(0) 104088900$

Fax: $\quad+31(0) 104089031$

Most TI discussion papers can be downloaded at http:/ /www.tinbergen.nl. 


\title{
THE TRADE AND FDI EFFECTS OF EMU ENLARGEMENT*
}

\author{
Jelle Brouwer ${ }^{\S}$, Richard Paap ${ }^{\ddagger}$ and Jean-Marie Viaene ${ }^{\S \S}$ \\ September 23, 2007 \\ (Forthcoming Journal of International Money and Finance)
}

\begin{abstract}
This paper considers the nature and the distribution of trade and FDI effects of a potential enlargement of the European Monetary Union (EMU) to the ten countries that obtained EU membership in 2004. Intuitively, the implementation of a single currency for these countries means replacing several fluctuating currencies by a common currency. This gives rise to both "level" and "risk" effects of reduced currency movements on trade and investment. Another factor is the nature of the link between trade and FDI. This is also important not only because cross-border factor flows are becoming increasingly important, but also the international trade literature has long recognized that cross-border factor flows and trade in goods and services can be substitutes or complements. Given this background, one-way and two-way error component gravity models are estimated to examine for these theoretical expectations within a dataset of unbalanced panel data that combines bilateral trade flows among 29 countries and the distribution of outward FDI stocks among these countries (including the 10 new EU members). The data generally cover the period from 1990 to 2004. Our empirical results convincingly support: (i) a complementarity between trade and investment, (ii) a relationship between trade and exchange rate volatility that depends on the sign of bilateral trade balances, (iii) a positive effect of EU on trade and investment, and (iv) a positive effect of EMU on foreign investment. Using a simulation-based technique, we find that estimates of FDI effects of EMU range between 18.5 percent for Poland and 30 percent for Hungary.
\end{abstract}

JEL Classification: C33, F21, F31, F33, F36

Keywords: EMU, exchange rate volatility, foreign investment, trade diversion, vertical integration.

\footnotetext{
${ }^{*}$ We gratefully acknowledge the helpful comments of Leon Bettendorf, Angelos Kanas, George Kouretas, James R. Lothian, Michael T. Melvin, Benoit Perron, Charles van Marrewijk, Vadym Volosovych, Casper de Vries, Eric van Wincoop, the seminar participants at Erasmus University and at the $11^{\text {th }}$ International Conference on Macroeconomic Analysis and International Finance held at the Department of Economics of the University of Crete (May 24-26, 2007). We thank especially Pierre Siklos, Dick J. van Dijk and an anonymous referee for detailed comments.

${ }^{\S}$ Erasmus University Rotterdam.

ॠ Erasmus University Rotterdam, Econometric Institute and Tinbergen Institute.

$\S \S$ (Corresponding Author) Erasmus University Rotterdam, Tinbergen Institute and CESifo. Address: Department of Economics, H8-8, Erasmus School of Economics, Erasmus University, P.O. Box 1738, 3000 DR Rotterdam, The Netherlands; e-mail: viaene@few.eur.nl; fax: 31-10-4089161; phone: 31-104081397.
} 


\section{Introduction}

The Accession Treaty of the European Union (EU) that entered into force on May 1, 2004 accredited the accession of ten new countries into the EU. This represented the biggest enlargement in European integration with more than 100 million citizens joining the $\mathrm{EU}^{1}$. Economic and political changes came dramatically fast in these countries as they, excepting Cyprus and Malta, adjusted from planned to market economies in 15 years. The next step in the integration process is to join the European Monetary Union (EMU) ${ }^{2}$. On the one hand, the prospect of euro membership helps stabilize these economies and the effective adoption of the euro as a common currency would generate the microeconomic benefits of a currency union. On the other hand, membership would imply the loss of macroeconomic flexibility of running an independent monetary policy. Hence, the question of what constitutes the benefits of EMU accession for new member countries assumes considerable importance.

An important factor affecting firms' foreign trade and investment decisions is the volatility in the major currencies of the world as illustrated by the behavior of the US dollar in the last two decades. Central to the issue is the popular conjecture that the floating exchange rate regime has led to a decrease in the volume of trade and in the investment flows by multinational firms. This view has been put forward repeatedly by governments and international organizations (see for example, UNCTAD, 1993, pp.224, Table XI.2). This paper examines the empirical premises of such conjecture.

Foreign direct investments (FDI) have grown dramatically as a major form of international capital transfer over the last few decades. Between 1990 and 2005 world stocks of FDI have approximately quintupled. The emerging global economy is one increasingly dominated by multinational firms that contribute to the internationalization of production chains. Currently they account for about one-third of world trade, intra-firm trade constituting the major component of such trade flows. One of the important features of FDI is that it is prominent in industries where the classical competitive paradigm fits least well. Regarding the ten new EU members a characteristic of the data is that they lag behind in attracting FDI as evidenced by UNCTAD's FDI performance index. The latter computes the ratio of a country's share in global FDI inflows to its share in global GDP. An index value of 1 implies the equality of

\footnotetext{
${ }^{1}$ The ten countries that became EU member in 2004 are: Cyprus, Czech Republic, Estonia, Hungary, Latvia, Lithuania, Malta, Poland, Slovakia and Slovenia. Slovenia joined the EMU on January 1, 2007.

${ }^{2}$ The European Monetary Union (EMU) exists since January 1, 1999 and comprises 12 countries. It substituted the euro for the national currencies of Austria, Belgium, France, Finland, Germany, Ireland, Italy, Luxembourg, The Netherlands, Portugal and Spain. Greece joined the EMU on January 1, 2001.
} 
both shares. In 2005, estimates range between 0.04 for Estonia to 0.92 for Slovenia (UNCTAD, 2006, Annex Table A.I.9). Therefore, the question of what can be the role of EMU in the trans-boundary investment behavior of enterprises becomes important for these countries.

The analysis of this paper considers variables such as trade and foreign direct investment, which are closely linked to the exchange rate. To that end, we estimate gravity models based on a dataset of unbalanced panel data that consists of bilateral trade flows among 29 countries and of the distribution of outward FDI stocks among these countries (including the ten new EU members). The data generally cover the period from 1990 to 2004, thus including the 2004 EU membership of the new countries. Whereas the existing literature aims at measuring the general effects of a common currency on trade (see e.g. Rose, 2004) or FDI (see e.g. De Sousa and Lochard, 2006; Petroulas, 2007), the contribution of the paper is to assess the implications of EMU enlargement for each individual country. These implications rest on the empirical tests of key propositions from the theoretical literature on the relationship between trade and FDI and on the role of exchange rate volatility on trade and investment. Our empirical results convincingly support: (i) a complementarity between trade and investment, (ii) a relationship between trade and exchange rate volatility that depends on the sign of bilateral trade balances, (iii) a positive effect of EU on trade and investment, and (iv) a positive effect of EMU on investment and a non-negative effect of EMU on trade. For Slovenia, for example, estimates of the effects of EMU on FDI are about 22 percent, those on trade about 8 percent.

The remainder of this paper is organized as follows. Section 2 provides a discussion of the empirical literature on the effects of the early introduction of EMU. Section 3 outlines the hypotheses to be tested. This is followed by the empirical tests in Section 4. Section 5 uses this evidence to compute the trade and FDI effects of a country-by-country enlargement of EMU. Section 6 discusses the consequences of the empirical results together with the scores of the ten new EU countries on the basis of the Maastricht criteria. Section 7 concludes. An Appendix describes the data methods and sources, and includes panel least square estimates with deflated variables.

\section{Related Literature}

Rose (2000) initiated a new stream in the empirical literature. He uses the gravity equation to estimate the separate effects of exchange rate volatility and currency unions on international trade. He finds a significant effect on trade for both variables. More specifically, the 
conclusion is that countries with a common currency would trade three times as much as countries that do not share a common currency. Further, bringing down the exchange rate volatility hypothetically to zero increases trade by 13 percent. These results led to numerous reactions, most of them questioning the large common currency effects on trade.

In his interpretive survey of the literature, Baldwin (2006) mentions the following drawbacks. First, a selection bias may arise because the data set used by Rose contains currency unions that involve many small and/or developing nations. As the EMU is exclusively built on developed countries his findings may not be applicable to Europe's single currency. Second, an important endogeneity issue may arise as well. If it were the case that countries that trade more with each other tend to form currency unions, then the estimated trade effects of currency unions cannot be interpreted as a pure currency union effect. Third, Rose's hypothesis is whether countries with a common currency trade more than countries without. For the EMU, the question is different, namely, has the euro caused a structural break in the data? Finally, the estimated effects using the gravity equation could suffer from non-linearity and omitted variables.

Taking care of most shortcomings of the existing literature, Micco et al. (2003) find more realistic effects of a currency union on trade: by joining the EMU, any two participating countries may increase their bilateral trade by 5 to 20 percent. In addition, there is the no evidence of trade diversion with non-member countries. This is important because potential gains for both member and non-member countries generate broad support for a currency union like the EMU.

The gravity model is the predominant functional form to infer the effects of institutions like regional trading agreements and exchange rate regimes. It is commonly used, mainly because it shows a high explanatory power. It is therefore not surprising to observe several attempts to develop its theoretical foundation (see Anderson, 1979; Deardorff, 1995; Helpman and Krugman, 1985; Bergstrand, 1989; Anderson and van Wincoop, 2003). For example, the insight of Anderson (1979), Anderson and van Wincoop (2003) is to show that trade between any two countries, after controlling for size, depends on a multilateral resistance term namely, bilateral barriers between them relative to average trade barriers that both countries face with the world.

In contrast, there are fewer theoretical foundations for the gravity equation for foreign investment flows. For example, Martin and Rey (2004) propose a theory of asset trade from which a gravity equation emerges. Testing the model, Portes and Rey (2005) show that it 
explains international transactions in financial assets with the same explanatory power as trade transactions. Regarding FDI, De Sousa and Lochard (2006) derive and test a gravity model based on the tradeoff between the benefits of a foreign affiliate of a multinational enterprise and the cost of its remoteness. In the model's reduced form, FDI depends on an inward effect, an outward effect (both related to countries' GDP), a bilateral effect (linguistic ties, colonial, physical distance) and a multilateral effect that represents the relative attractiveness of alternative locations.

\section{Main Testable Hypotheses}

The theoretical literature has derived a number of hypotheses regarding the relationship between trade and FDI and the role of exchange rate volatility on trade and investment. Tests of these key propositions are important as most effects of EMU enlargement rest on the sign and value of these key estimates. These hypotheses are outlined below; the explanatory variables used to test each hypothesis are given within parentheses. Expected signs are summarized in Table 1.

\section{Significance of EMU (EMU2)}

Rose (2004) performs a meta-analysis of all studies that had investigated the effect of a currency union on trade till that date, thirty-four in total. He concludes that the hypothesis that there is no effect of currency unions on trade can be rejected at conventional significance levels. It is therefore safe to assume that the EMU has increased trade.

Though such a meta-analysis is not yet available for FDI, most empirical studies show a positive effect. In De Sousa and Lochard (2006) for example, the introduction of the euro raises FDI stocks among EMU countries by about 29 percent on average. In Petroulas (2007), it is estimated that the EMU increases inward FDI flows by about 16 percent within the euro area. There is also evidence of positive spillovers from EMU on partner countries within the European Union. Hence, these increases parallel those obtained for trade volumes. ${ }^{3}$

\footnotetext{
${ }^{3}$ But, what are the reasons for the positive effects? First, the elimination of currency exchange costs is an obvious benefit. Also, the increased transparency in the international comparison of prices facilitates the arbitrage of goods across national boundaries. Simultaneously, search engines of the internet have provided the technology to perform arbitrage more efficiently. Second, the emergence of the euro as a reserve currency qualifies it as a prime currency of invoice for trade with non-member countries. For the euro zone, this is an additional element of stability as it shifts the exchange rate risk to trade partners. Third, with the announcement and introduction of the euro, real returns to capital have converged almost completely among participating countries. For countries with historically high interest rates, this meant a boost to new investments, higher growth and trade.
} 
Table 1 Expected Signs

\begin{tabular}{|lcc|}
\hline Explanatory variables & Export & $\begin{array}{c}\text { Outward FDI } \\
\text { Stock }\end{array}$ \\
\hline ln GDP country $i$ & + & + \\
$\ln$ GDP country $j$ & + & + \\
& & - \\
ln distance & - & $+/-$ \\
contiguity & + & + \\
language & + & \\
& & \\
ln FDI (of $i$ in $j$ ) & $+/-$ & \\
& & \\
TB*ln volatility & - & \\
$\ln$ volatility & & - \\
& & + \\
XR change & 0 & + \\
XR appreciation & & $+/-$ \\
XR depreciation & & + \\
& & $+/-$ \\
EU2 & & $+/-$ \\
EU1 & + & $+/-$ \\
EMU2 & $+/-$ & \\
EMU1(new) & & + \\
EMU1(ru) & $+/-$ & +- \\
EMU1(rw) & $+/-$ & \\
\hline
\end{tabular}

\section{Significance of EU (EU2)}

Several empirical studies have examined the hypothesis that a free trade agreement (FTA) increases members' trade and share of FDI. In a recent study of trade, Baier and Bergstrand (2007) use a gravity model and show that a FTA approximately doubles two members' bilateral trade after 10 years. Regarding FDI, it is a matter of empirical research to characterize this relationship. Besides that, though there are a number of theoretical studies that look at trade diversion (EU1), the empirical studies do not really support the hypothesis (see e.g. Bowen et al., 1998, chapter 12).

\section{Trade and FDI: Substitutes or Complements (ln FDI)}

Mundell (1957) is credited with the first formal analysis of the interaction between the international flow of goods and factors. Adopting the neo-classical model of trade, but relaxing the assumption of international factor immobility, Mundell derived the result that an increase in trade impediments stimulates factor movements and an increase in restrictions to factor movements stimulates trade. More generally, the result states that goods trade and 
factor flows are substitutes. In contrast, some have searched for explanations for complementarity within the context of received trade models. Markusen's (1983) analysis offers one such attempt.

Since alternative theoretical models predict opposite results concerning the relationship between the international trade in goods and in factors, it is a matter of empirical research to characterize this relationship. Previous research efforts have dealt with this issue but most recent studies conclude on a positive correlation between the international flow of goods and factors (see e.g. Wong, 1988; Brenton et al., 1999). ${ }^{4}$

\section{Trade and Conditional Volatility of Exchange Rates (TB* In volatility)}

Fluctuations in foreign currencies matter for foreign investment because of the forwardlooking behavior of multinationals when they make decisions to locate abroad. They matter for trade because of the common practice in international trade to extent trade credits. Hence, there is a time gap between the delivery date of goods and the payment date. These fluctuations give rise to both "level" and "risk" effects.

Regarding risk, theory in this field is rather simple in the sense that there is one main result namely, the separation theorem: in the presence of forward markets, the volume of trade is independent of the distributions of the exchange rate and of the type of utility function of the exporter (Edor and Zilcha, 1991). The implication is that any two firms with the same cost function but with different attitudes toward risk, and with different probability beliefs about the future exchange rate, will produce the same level of output. This is the important contribution of a forward market. If the separation result holds, the exporter avoids exchange risk altogether and is indifferent between the EMU or a flexible exchange rate regime.

Several empirical studies have examined the hypothesis that increases in the conditional volatility of exchange rates reduce trade. The results differ depending on whether the analysis assumes the existence of a well-developed forward market. Studies of developing countries in which forward markets are absent generally find a negative relationship between trade and exchange rate volatility (Coes, 1981). For countries with forward markets, no consistent link between volatility and trade has been found (Klaassen, 2004).

\footnotetext{
${ }^{4}$ For example, Wong (1988) estimates the effects of the movements of capital and labor on the volume of trade and factor prices of the United States over the period 1948-83. His results suggest a strong complementarity result between factor supplies and international trade. This implies that any increase in US factor endowments causes an increase in the volume of US trade (exports and imports) with the rest of the world.
} 
In an attempt to reconcile the theory with empirics, Viaene and de Vries (1992) relax the assumption of exogenous forward rates necessary to derive the separation theorem and solve for the forward rate in terms exchange rate volatility whose sign is the negative of the net foreign currency exposure of an economy. Since importers and exporters are on opposite sides of the forward market, so is their exposure towards conditional exchange rate volatility. As gravity models consider both bilateral exports and imports to a single country, they are the ideal setup to test this relationship. To that end, we take the bilateral trade balance (TB) as a proxy for net aggregate foreign currency exposure and multiply it by the natural logarithm of volatility ( $\mathrm{TB}^{*} \ln$ volatility). Assume $\mathrm{TB}<0$. An increase in volatility in this framework leads to a depreciation of the home currency, which in turn increases exports. In contrast, when $\mathrm{TB}>0$, an increased volatility decreases exports. The expected sign is therefore negative.

\section{FDI and Conditional Volatility of Exchange Rates (In volatility)}

Though there are numerous theoretical studies that look at how the conditional volatility of exchange rates affects foreign investment, no separation theorem has been derived for this case. For example, Broll and Zilcha (1992) show that in a model of horizontal product differentiation the effects of volatility (more precisely, a second-order decrease in the distribution of the exchange rate) depend on the shape of the profit function. Another interesting result is that in models of vertical product differentiation the reduced form expected gain from investment is a strictly convex function of the uncertain exchange rate. Therefore, an increase in foreign exchange variability has a positive effect on vertical foreign direct investment (Roy and Viaene, 1998). To the extent that strategic control of vertical production is an important motive for foreign investment, this last result indicates there is a theoretical basis for increased volatility of exchange rates having a positive effect on FDI.

\section{Exchange Rates and Trade (XR change)}

A robust result of models of trade and exchange rates is that the terms of trade effect has the correct sign and is significant. If the exchange rate is defined as the number of units of domestic currency per unit of foreign currency (an increase is a depreciation), the expected level of the exchange rate is positively correlated with exports. However, since gravity models consider both bilateral exports of country $i$ to country $j$ and of country $j$ to $i$ (imports

of country $i$ ), the sign is expected to be null if trade balances are in equilibrium. 


\section{Exchange Rates and FDI: Hysteresis (XR depreciation, XR appreciation)}

As for the effect of a change in the expected level of exchange rate on direct investment, the empirical literature has provided mixed answers. On the one hand, a depreciation of the domestic currency can decrease the relative wealth of domestic firms and therefore their relative ability to undertake mergers and acquisitions (see Froot and Stein, 1991). In models of vertical integration, a depreciation of the investor's currency increases both the effective arms length price at which a unit of the intermediate good can be bought in the market and the unit cost of producing the good directly through a subsidiary: the net effect is always a reduction in the incentive to undertake FDI.

On the other hand, models on hysteresis like in Dixit (1992) look for possible asymmetries in the response to exchange rate movements: exchange rate depreciations are expected to lead to entry events in industries whereas exchange rate appreciations do not necessarily lead to exits. In order to test for asymmetry in exchange rate changes we split our observations into exchange rate appreciations (XR appreciation) and exchange rate depreciations (XR depreciation). For hysteresis to hold, the sign of depreciations is expected to be positive and significantly different in absolute value of that of appreciations.

\section{Model Specification and Estimates}

The objective of this section is to outline the functional forms of the models to be estimated, to define the variables of the models, to report and discuss empirical results.

\subsection{Functional Forms}

In order to formally assess the effects of EMU on trade and FDI flows we use two different models that have been fairly used in the empirical literature (Baltagi, 2005). The first model is the so-called one-way error component model where a dependent variable $y_{i j t}$ is explained by a set of $K$ explanatory variables $X_{i j t}$ and time-invariant unobserved country fixed effects $\alpha_{i}$ and $\alpha_{j}$. Formally, the model is written as:

$$
y_{i j t}=\alpha_{i}+\alpha_{j}+X_{i j t}^{\prime} \beta+\varepsilon_{i j t}, \quad \quad i, j=1, \ldots N ; i \neq j ; t=1, \ldots T,
$$

where $N$ is the number of countries and $T$ the number of yearly observations. $\varepsilon_{i j t}$ is the remainder stochastic disturbance with $\varepsilon_{i j t} \sim \operatorname{IID}\left(0, \sigma^{2}\right)$. In our framework $y_{i j t}$ stands for the natural logarithm of exports of country $i$ to country $j$ in the trade equation and the natural logarithm of the outward stock of FDI of country $i$ in country $j$ in the FDI equation. 
Application of the model leads to the estimation of $2 \mathrm{~N}$ country parameters. The fixed effects of exporter country $i$ and importer country $j$ are included to control for time-invariant countryspecific heterogeneity. This model is used in cross-section regressions of the gravity model derived by Anderson and van Wincoop (2003) that includes "multilateral resistance" terms capturing country i's and country $j$ 's resistance to trade with all regions. Since multilateral resistance terms are not observables, Feenstra (2002) shows that consistent estimates of the model can be obtained by using exporter and importer fixed effects. The same logic is applied to the FDI specification to proxy a multilateral effect that represents the relative attractiveness of alternative investment locations.

An alternative specification of the one-way error component model is the bilateral fixed effects model where $\alpha_{i}$ and $\alpha_{j}$ in (1) are replaced by time-invariant unobserved country pair effects $\alpha_{i j}$ :

$$
y_{i j t}=\alpha_{i j}+X_{i j t}^{\prime} \beta+\varepsilon_{i j t}, \quad \quad i, j=1, \ldots N ; i \neq j ; t=1, \ldots, . T .
$$

The estimation of (2) involves estimating $N(N-1)$ country pair parameters $\alpha_{i j}$. Bilateral fixed effects between countries $i$ and $j$ are included to control for influences to the trade and investment of a country pair. Border transactions, seasonal trade, investment preferences, bilateral treaties, etc. are controlled for with these time-invariant specific effects. Micco et al. (2003), Flam and Nordström (2003) have used such a specification.

The second model is the two-way error component model that accounts for any time-specific effect that is not included in the regression:

$$
y_{i j t}=\alpha_{i}+\alpha_{j}+\lambda_{t}+X_{i j t}^{\prime} \beta+\varepsilon_{i j t}, \quad \quad i, j=1, \ldots N ; i \neq j ; t=1, \ldots T,
$$

where $\lambda_{t}$ denotes the unobservable time effect. There are $T$ such time effects. This model controls for omitted variables that vary over time but remain constant across countries. Likewise, the counterpart of (2) with unobservable time effects is:

$$
y_{i j t}=\alpha_{i j}+\lambda_{t}+X_{i j t}^{\prime} \beta+\varepsilon_{i j t}, \quad \quad i, j=1, \ldots N ; i \neq j ; t=1, \ldots, . T .
$$

However, in panel data regressions, an alternative specification of (4) is also used:

$$
y_{i j t}=\alpha_{i t}+\alpha_{j t}+X_{i j t}^{\prime} \beta+\varepsilon_{i j t}, \quad \quad i, j=1, \ldots N ; i \neq j ; t=1, \ldots T,
$$

where the country fixed effects are now made time dependent. Equation (5) includes $2 N T$ dummies in the regression. It is unusual to estimate time dependent country pair effects in (5) 
since the specification includes $N(N-1) T$ dummies and its estimation suffers from a too large loss of degrees of freedom.

\subsection{Definition of Variables}

As in Flam and Nordström (2003), the dependent variable in the export equation is the natural $\log$ of bilateral export flows from country $i$ to country $j .{ }^{5}$ For FDI it is the natural log of the stock of outward FDI from country $i$ in country $j$. Here, the concept of stocks is preferred to flows as they are more persistent through time. As in Anderson and van Wincoop (2003), Portes and Rey (2005) dependent variables are expressed in nominal terms:

$\ln$ export $=\log$ of nominal bilateral exports from country $i$ to country $j$ in US $\$$;

$\ln$ FDI $=\log$ of nominal outward FDI stock of country $i$ in country $j$ in US $\$$.

To assess the direct effects of EMU on trade and FDI the $K$ explanatory variables $X_{i j t}$ include a number of time-varying binary variables that are meant to measure the potential benefits of EMU:

$E M U 2=1$ when country $i$ and $j$ are both EMU members at date $t ;=0$ otherwise;

EMU1(new) $=1$ when country $i$ is EMU member, country $j$ is outside the EMU but belongs to the new "ten" at date $t ;=0$ otherwise;

EMU1(ru) $=1$ when country $i$ is EMU member, country $j$ is either Denmark, Sweden, U.K at date $t ;=0$ otherwise;

$\operatorname{EMU1}(r w)=1$ when country $i$ is EMU member, country $j$ is outside EMU and EU at date $\mathrm{t} ;=0$ otherwise;

$E U 2=1$ when country $i$ and $j$ are both EU members at date $t ;=0$ otherwise;

$E U 1=1$ when country $i$ only is EU member at date $t ;=0$ otherwise.

The dummy variables EMU2 and EU2 are introduced separately as they represent two separate forms of economic integration: the first one, a first variable of interest, is an estimate of the marginal contribution of EMU for participating countries whereas the second is an estimate of the marginal contribution of EU for member countries. All other dummies are introduced to estimate the extent of trade diversion and the extent of FDI diversion for

\footnotetext{
${ }^{5}$ It is more common to take the average of the logs of export and import. However, using unilateral trade flows eases the interpretation of home and partner effects.
} 
different country groupings. ${ }^{6}$ Year of EU entry and/or EMU entry of each country is given in the Appendix.

As EMU enlargement means replacing several fluctuating currencies by a common currency the "level" and "risk" effects of exchange rates are important. Exchange rates are defined as the number of units of domestic currency per unit of foreign currency. Hence, the bilateral exchange rate is expressed as the number of units of exporter's currency per unit of importer's currency. Changes are expressed in percentage changes. Volatility is measured as the standard deviation of the monthly percentage changes within a year. In particular:

ln volatility $=\log$ of exchange rate volatility, where volatility is defined as the standard deviation of the monthly percentage changes in the real exchange rate within a year;

$\mathrm{TB}^{*} \ln$ volatility $=$ bilateral trade balance times $\ln$ volatility; TB is log bilateral exports minus log bilateral imports.

$\mathrm{XR}$ change $=$ exchange rate change, measured as the percentage change in the level of the exchange rate within a year;

$\mathrm{XR}$ depreciation $=$ positive percentage changes in the level of the exchange rate;

$\mathrm{XR}$ appreciation $=$ negative percentage changes in the level of the exchange rate.

As bilateral trade depends on market size, we use nominal GDP as a proxy for size in source and destination country in the trade equation. Likewise in the FDI equation:

$\ln \mathrm{GDP}_{i}=\log$ of nominal GDP in US $\$$ of country $i$;

$\ln \mathrm{GDP}_{j}=\log$ of nominal GDP in US $\$$ of country $j$.

Our gravity equations include also standard gravity variables like distance, contiguity, and language:

\footnotetext{
${ }^{6}$ In the case of trade, for example, trade diversion is traditionally the amount of trade diverted by a free trade area when imports from a non-member country are replaced by imports from a partner country. Applied to the context of the EMU, trade diversion occurs if trade with non-EMU countries decreases namely, a significant negative sign is obtained for the EMU1 variables. A significant positive sign is indicative of external trade creation.
} 
ln distance $=\log$ of distance between capital cities of country $i$ and $j$ in kilometer;

contiguity $=1$ when countries $i$ and $j$ share a common border; $=0$ otherwise;

language $=1$ when countries $i$ and $j$ share a common official language $;=0$ otherwise.

These variables are usually not included in specifications with country pair fixed effects as they characterize bilateral transactions among source and destination countries. Otherwise, distance is a measure of transport costs in physical trade, and in investment decisions it is a proxy for costs in information transmission within multinationals.

The above set of explanatory variables gives rise to a sample with the broadest coverage, i.e., one that includes the internal market programme and the introduction of the euro. Variables that have been found to be significant in prior empirical investigations, like equity market capitalization (Portes and Rey, 2005), the stock market indices and payoffs of investment (Petroulas, 2007) have not been included, usually because of too few observations if they exist. The inclusion of other variables like income per capita and real wages, that are largely available, did not lead to conclusive results.

\subsection{Empirical Results}

We use panel data to estimate equations (1) to (5). Our sample contains 29 countries $(N=29)$ : all 25 countries that were EU member in 2004 and a control group that consists of Switzerland, Japan, Canada, and the United States. This gives 28 bilateral relationships per country over a period ranging from 1990 till 2004 and, in principle, a balanced dataset of 12180 observations. However, because of missing observations this dataset is unbalanced. Unilateral data on exports are obtained from the IMF Direction of Trade Statistics. For FDI we use the outward stocks as published by the OECD. The limited availability of FDI data is the constraining factor since it limits the time span to fifteen years $(T=15)$. Moreover it has a missing rate of approximately fifty percent. The Appendix provides more details regarding data methods and sources.

This section reports regression estimates of the models in value terms. Using panel data, special attention will therefore be given to the time dummies. For the sake of comparison the Appendix reproduces some of our results using deflated variables instead but differences are negligible. 
Estimation results of equations (1) to (4), performed using panel least squares of Eviews 5.0, are reported in Tables 2, 3, 4 and 5. Estimates of equation (5) are not reproduced as they show almost no concordance with expected signs of Table 1 . The difficulty with this model lies in the estimation of about 870 dummies that give rise to numerous data problems. In particular, too few observations on some country pairs prevent the estimation of some dummy variables ${ }^{7}$. In each table the first part reports the results for export and the second part the results for FDI. Across the four model specifications, we have a number of robust and significant parameter estimates. For example, it is clear that EMU has a positive effect on FDI. Less robust is the effect on trade since EMU2 has only a significant positive sign for exports in Tables 3 and 5 where country pair fixed effects are used. The sign of volatility on trade is consistently negative and significant. Regarding the EU2 dummy, the effects are systematically positive, which is indicative of the beneficial effects of EU for trade and investment. Another robust finding is the absence of trade and investment diversion for the ten new EU member states. This is seen from the estimates of the EMU1(new) dummy, which is non-negative throughout. Since estimates of EMU1(new) are often larger than those of EMU2, they probably also capture the transition effects of the new EU countries, as they moved from a closed to an open economy. Also, FDI is negatively related to exchange rate depreciations (though not always significant), a result which does not support the hysteresis hypothesis. The sign of distance is negative for trade and investment, which suggests that in the latter case it captures the cost of information transmission within international firms.

\footnotetext{
${ }^{7}$ Given the forward-looking behaviour of traders and investors, we estimate two separate versions of (1) to (5), one with current volatilities, another with expected volatilities. As a proxy for the latter, we use one-period ahead volatilities (at date $t+1$ ). It turns out that there is almost no difference in the outcomes, the reason being that volatilities constructed on a yearly basis show strong persistence through time. Hence, we only report results with current volatilities.
} 
Table 2 Country Fixed Effects

\begin{tabular}{|c|c|c|c|c|}
\hline \multirow{3}{*}{$\begin{array}{l}\text { Explanatory } \\
\text { variables }\end{array}$} & \multicolumn{4}{|c|}{ Equation (1) } \\
\hline & \multicolumn{2}{|c|}{ ln export } & \multicolumn{2}{|c|}{$\ln$ FDI } \\
\hline & $(1)$ & $(2)$ & (3) & (4) \\
\hline $\ln \mathrm{GDP}_{\mathrm{i}}$ & $0.353(0.000)$ & & $1.135(0.000)$ & \\
\hline $\ln \mathrm{GDP}_{\mathrm{j}}$ & $0.415(0.000)$ & & $1.421(0.000)$ & \\
\hline In distance & $-0.714(0.000)$ & $-0.676(0.000)$ & $-0.963(0.000)$ & $-0.908(0.000)$ \\
\hline contiguity & $0.396(0.000)$ & $0.398(0.000)$ & $0.294(0.003)$ & $0.331(0.001)$ \\
\hline language & $0.218(0.000)$ & $0.202(0.000)$ & $0.341(0.001)$ & $0.337(0.001)$ \\
\hline $\ln \mathrm{FDI}$ & $0.159(0.000)$ & $0.184(0.000)$ & & \\
\hline TB* ln volatility & $-0.084(0.000)$ & $-0.082(0.000)$ & & \\
\hline ln volatility & & & $0.106(0.006)$ & $0.064(0.110)$ \\
\hline XR change & $-0.015(0.134)$ & $-0.011(0.268)$ & & \\
\hline XR appreciation & & & $0.049(0.202)$ & $0.046(0.251)$ \\
\hline XR depreciation & & & $-0.060(0.180)$ & $-0.051(0.279)$ \\
\hline EU2 & $0.106(0.013)$ & $0.266(0.000)$ & $0.433(0.000)$ & $1.001(0.000)$ \\
\hline EU1 & $-0.060(0.193)$ & $0.058(0.214)$ & $-0.071(0.587)$ & $0.325(0.016)$ \\
\hline EMU2 & $0.055(0.090)$ & $0.114(0.001)$ & $0.737(0.000)$ & $0.969(0.000)$ \\
\hline EMU1(new) & $0.115(0.001)$ & $0.196(0.000)$ & $0.651(0.000)$ & $0.966(0.000)$ \\
\hline EMU1(ru) & $0.035(0.489)$ & $0.093(0.075)$ & $0.528(0.000)$ & $0.740(0.000)$ \\
\hline EMU1(rw) & $-0.054(0.221)$ & $0.040(0.382)$ & $0.241(0.072)$ & $0.666(0.000)$ \\
\hline $\bar{R}^{2}$ (adjusted) & 0.934 & 0.931 & 0.821 & 0.804 \\
\hline $\bar{R}^{2}$ (adj, within) & 0.703 & 0.687 & 0.314 & 0.250 \\
\hline
\end{tabular}

Notes: (i) panel least squares with country dummies; (ii) p-values in parentheses; (iii) No. of observations in columns (1) and (2) $=4152$; (iv) No. of observations in columns (3) and (4) = 3542 , as we impose FDI $>0.01$; (v) within $\bar{R}^{2}$ is computed on demeaned data. 
Table 3 Country Pair Fixed Effects

\begin{tabular}{|c|c|c|}
\hline \multirow{3}{*}{$\begin{array}{l}\text { Explanatory } \\
\text { variables }\end{array}$} & \multicolumn{2}{|c|}{ Equation (2) } \\
\hline & ln export & $\ln$ FDI \\
\hline & (1) & (2) \\
\hline $\ln \mathrm{GDP}_{\mathrm{i}}$ & $0.480(0.000)$ & $1.413(0.000)$ \\
\hline $\ln \mathrm{GDP}_{\mathrm{j}}$ & $0.568(0.000)$ & $1.245(0.000)$ \\
\hline $\ln \mathrm{FDI}$ & $0.033(0.000)$ & \\
\hline $\mathrm{TB}^{*} \ln$ volatility & $-0.060(0.000)$ & \\
\hline ln volatility & & $-0.061(0.013)$ \\
\hline XR change & $0.010(0.017)$ & \\
\hline $\mathrm{XR}$ appreciation & & $0.095(0.025)$ \\
\hline XR depreciation & & $-0.014(0.676)$ \\
\hline EU2 & $0.129(0.000)$ & $0.237(0.001)$ \\
\hline EU1 & $0.074(0.001)$ & $-0.129(0.134)$ \\
\hline EMU2 & $0.144(0.000)$ & $0.569(0.000)$ \\
\hline EMU1(new) & $0.383(0.000)$ & $1.222(0.000)$ \\
\hline EMU1(ru) & $0.046(0.047)$ & $0.806(0.000)$ \\
\hline EMU1(rw) & $0.117(0.000)$ & $0.437(0.000)$ \\
\hline Constant & $0.786(0.000)$ & $-9.927(0.000)$ \\
\hline $\bar{R}^{2}$ (adjusted) & 0.991 & 0.946 \\
\hline $\bar{R}^{2}$ (adj, within) & 0.640 & 0.428 \\
\hline
\end{tabular}

Notes: (i) panel least squares with country pair dummies; (ii) p-values in parentheses; (iii) No. of observations in column (1) $=4152$; (iv) No. of observations in column $(2)=3542$, as we impose FDI $>0.01 ;(\mathrm{v})$ within $\bar{R}^{2}$ is computed on demeaned data. 
Table 4 Country Fixed Effects and Time-specific Effects

\begin{tabular}{|c|c|c|c|c|}
\hline \multirow{3}{*}{$\begin{array}{l}\text { Explanatory } \\
\text { variables }\end{array}$} & \multicolumn{4}{|c|}{ Equation (3) } \\
\hline & \multicolumn{2}{|c|}{ ln export } & \multicolumn{2}{|c|}{$\ln \mathrm{FDI}$} \\
\hline & (1) & (2) & (3) & (4) \\
\hline $\ln \mathrm{GDP}_{\mathrm{i}}$ & $0.426(0.000)$ & & $0.922(0.001)$ & \\
\hline $\ln \mathrm{GDP}_{\mathrm{j}}$ & $0.461(0.000)$ & & $1.230(0.000)$ & \\
\hline In distance & $-0.714(0.000)$ & $-0.704(0.000)$ & - $0.964(0.000)$ & $-0.954(0.000)$ \\
\hline contiguity & $0.398(0.000)$ & $0.408(0.000)$ & $0.300(0.002)$ & $0.331(0.001)$ \\
\hline language & $0.218(0.000)$ & $0.208(0.000)$ & $0.342(0.001)$ & $0.331(0.001)$ \\
\hline $\ln \mathrm{FDI}$ & $0.158(0.000)$ & $0.163(0.000)$ & & \\
\hline $\mathrm{TB}^{*} \ln$ volatility & $-0.085(0.000)$ & $-0.084(0.000)$ & & \\
\hline In volatility & & & $0.144(0.000)$ & $0.162(0.000)$ \\
\hline XR change & $-0.009(0.403)$ & $-0.002(0.864)$ & & \\
\hline XR appreciation & & & $0.054(0.159)$ & $0.062(0.111)$ \\
\hline XR depreciation & & & $-0.067(0.131)$ & $-0.068(0.132)$ \\
\hline EU2 & $0.100(0.026)$ & $0.104(0.023)$ & $0.470(0.003)$ & $0.480(0.000)$ \\
\hline EU1 & $-0.063(0.183)$ & $-0.060(0.208)$ & $-0.059(0.659)$ & $-0.062(0.650)$ \\
\hline EMU2 & $0.012(0.763)$ & $-0.023(0.538)$ & $0.410(0.000)$ & $0.338(0.002)$ \\
\hline EMU1(new) & $0.063(0.176)$ & $0.055(0.229)$ & $0.329(0.010)$ & $0.327(0.010)$ \\
\hline EMU1(ru) & $-0.011(0.836)$ & $-0.055(0.320)$ & $0.164(0.293)$ & $0.044(0.778)$ \\
\hline EMU1(rw) & $-0.102(0.039)$ & $-0.144(0.004)$ & $-0.109(0.456)$ & $-0.201(0.170)$ \\
\hline $\bar{R}^{2}$ (adjusted) & 0.935 & 0.934 & 0.824 & 0.821 \\
\hline $\bar{R}^{2}$ (adj, within) & 0.691 & 0.686 & 0.236 & 0.225 \\
\hline
\end{tabular}

Notes: (i) panel least squares with country and year dummies; (ii) p-values in parentheses; (iii) No. of observations in columns (1) and (2) $=4152$; (iv) No. of observations in columns (3) and (4) $=3542$, as we impose FDI $>0.01$; (v) within $\bar{R}^{2}$ is computed on demeaned and detrended data. 
Table 5 Country Pair Fixed Effects and Time-specific Effects

\begin{tabular}{|c|c|c|}
\hline \multirow{3}{*}{$\begin{array}{l}\text { Explanatory } \\
\text { variables }\end{array}$} & \multicolumn{2}{|c|}{ Equation (4) } \\
\hline & ln export & $\ln$ FDI \\
\hline & $(1)$ & (2) \\
\hline $\ln \mathrm{GDP}_{\mathrm{i}}$ & $0.522(0.000)$ & $1.193(0.000)$ \\
\hline $\ln \mathrm{GDP}_{\mathrm{j}}$ & $0.590(0.000)$ & $1.060(0.000)$ \\
\hline $\ln \mathrm{FDI}$ & $0.020(0.000)$ & \\
\hline $\mathrm{TB}^{*}$ ln volatility & $-0.063(0.000)$ & \\
\hline ln volatility & & $-0.019(0.437)$ \\
\hline XR change & $0.016(0.000)$ & \\
\hline $\mathrm{XR}$ appreciation & & $0.100(0.015)$ \\
\hline XR depreciation & & $-0.027(0.388)$ \\
\hline EU2 & $0.127(0.000)$ & $0.252(0.001)$ \\
\hline EU1 & $0.069(0.001)$ & $-0.102(0.228)$ \\
\hline EMU2 & $0.067(0.000)$ & $0.192(0.003)$ \\
\hline EMU1(new) & $0.305(0.000)$ & $0.830(0.000)$ \\
\hline EMU1(ru) & $-0.032(0.178)$ & $0.419(0.000)$ \\
\hline EMU1(rw) & $0.032(0.130)$ & $0.037(0.678)$ \\
\hline Constant & $0.476(0.112)$ & $-7.178(0.000)$ \\
\hline $\bar{R}^{2}$ (adjusted) & 0.992 & 0.950 \\
\hline $\bar{R}^{2}$ (adj, within) & 0.337 & 0.085 \\
\hline
\end{tabular}

Notes: (i) panel least squares with country pair and year dummies; (ii) p-values in parentheses; (iii) No. of observations in column (1) $=4152$; (iv) No. of observations in column $(2)=3542$, as we impose FDI $>0.01$; (v) within $\bar{R}^{2}$ is computed on demeaned and detrended data.

Finally, a crucial result of our empirical analysis is that the link between FDI and trade is positive and significant. This implies that the euro affects trade through two channels: (i) a direct effect due to the microeconomic benefits of a common currency and (ii) an indirect effect due to its stimulating effects on FDI.

These last results are consistent with the idea that industrial production can be more efficient if it splits into separate stages. Various stages need not be located in the same country if it is easy to ship products from place to place. Participation to EMU is a potential contributor to this international division of labor by lowering uncertainty and making markets more transparent. Competing firms in the same market tend also to invest upstream in a particular region because rival firms do. A typical outcome is that the decrease in the fixed cost of investment brought about by the EMU (because of lower transaction costs, lower interest 
rates, etc.) can trigger a jump in the volume of foreign investment. Trade with these regions increases as well and takes the form of intra-firm trade. ${ }^{8}$

Given this let us now select the estimated equations to be used later in our simulation experiments. To that end we perform likelihood ratio tests of specification in Tables 6, 7 and 8. Based on Table 6 we reject the null hypothesis that the effects of $\mathrm{GDP}_{i}$ and $\mathrm{GDP}_{j}$ are null. This is also supported by the individual p-values in Tables 2 and 4 . The contribution of both variables in the trade and investment equations is significant at any conventional significance level. Likewise in Table 7, we reject the null hypothesis that the time-specific fixed effects are null. They are significant at any conventional significance level as well. Hence, we can conclude that the best models are those of Table 4 (columns 1 and 3 ) and of Table 5.

\section{Table 6 Likelihood Ratio Tests of the Inclusion of GDP}

\begin{tabular}{|l|ll|ll|}
\hline \multirow{2}{*}{} & \multicolumn{2}{|c|}{ Export } & \multicolumn{2}{c|}{ FDI } \\
\cline { 2 - 5 } & Table 2 & Table 4 & Table 2 & Table 4 \\
\hline $\mathrm{H}_{0}$ & col. 2 & col. 2 & col. 4 & col. 4 \\
LR test & col. 1 & col. 1 & col. 3 & col. 3 \\
Degrees of freedom & 226.560 & 67.562 & 323.632 & 53.532 \\
p-value & 2 & 2 & 2 & 2 \\
\hline \hline
\end{tabular}

\footnotetext{
${ }^{8}$ This is weak evidence in favour of vertical motivations for FDI. Stronger evidence could be obtained by testing a knowledge-capital model like in Carr et al. (2001) and Bloningen et al. (2003) that combines both horizontal and vertical arguments for FDI. Though the knowledge-capital model is not tested here, it lends itself to an interpretation of EMU enlargement. In the model, firms with horizontal FDI set up plants close to final demand and are influenced in their decisions by trade costs and market size. In contrast, firms with vertical FDI carry out unskilled-labor production in locations with relatively high endowments in unskilled labor. When countries join the EMU trade costs with member countries are expected to decrease. This gives more incentive for vertically integrated firms to expand and ship their goods across locations and less incentive for horizontally integrated firms to "jump" into the euro area, build a plant and sell their products directly. The net effect is an empirical question and our empirical results support the idea that vertical FDI dominates horizontal FDI.
} 
Table 7 Likelihood Ratio Tests of the Significance of Time-specific Effects

\begin{tabular}{|l|cc|cc|}
\hline \hline & \multicolumn{2}{|c|}{ Export } & \multicolumn{2}{c|}{ FDI } \\
\hline $\mathrm{H}_{0}$ & Eq. (1) & Eq. (2) & Eq. (1) & Eq. (2) \\
LR test & Eq. (3) & Eq. (4) & Eq. (3) & Eq. (4) \\
Degrees of freedom & 50.432 & 60.414 & 382.536 & 277.53 \\
p-value & 14 & 14 & 14 & 14 \\
\hline \hline
\end{tabular}

Table 8 Likelihood Ratio Tests of Fixed Effects

\begin{tabular}{|l|c|c|}
\hline \hline & Export & FDI \\
\hline \hline $\mathrm{H}_{0}$ & Eq. (3) & Eq. (3) \\
LR test & Eq. (4) & Eq. (4) \\
Degrees of freedom & 545 & 545 \\
p-value & 0.000 & 0.000 \\
\hline \hline
\end{tabular}

Finally, like in Baltagi et al. (2003), we report the likelihood ratio tests that discern between these two models in Table 8. It is clear that we can reject the null hypothesis that equation (3) is the true model. Equation (4) is preferred as the contribution of country pair fixed effects (together with time-specific fixed effects) is significant at any conventional significance level. $^{9}$

\section{EMU Enlargement}

The effects of EMU enlargement for each individual country can be approximated using a simulation-based technique that involves the following three steps:

\footnotetext{
${ }^{9}$ The GDP variables are usually subsumed in fixed effects in cross-section analyzes. However, in our framework with panel data, tests of Table 6 support their inclusion. To further characterize their role in our preferred equation (4), F-tests and Wald-tests imply the following at any conventional significance level: (i) rejection of the homogeneity of degree 1 in the export equation; (ii) failure to reject homogeneity of degree 1 in the FDI equation; (iii) rejection of the null hypothesis that estimates of GDPs in the export equation are different; (iv) rejection of the null hypothesis that estimates of GDPs in the FDI equation are different.
} 
Step 1: to simulate our estimated models to obtain the value of trade and FDI that arises in absence of EMU enlargement. This is our base scenario. ${ }^{10}$

Step 2: to compute the counterfactual, that is, to compute the amount of trade and FDI that would arise if each of the ten new EU members had joined the euro zone in 2004, one by one. This is the counterfactual scenario.

Step 3: to compute percentage differences between the counterfactual and the base scenario. This gives our estimates of EMU enlargement.

These steps are reproduced for each of the ten possible entrants and results are shown in Table 9.

Table 9 Effects of EMU Enlargement: Model with Country Pair and Time-specific Fixed Effects

\begin{tabular}{|c|c|c|c|c|c|c|c|c|c|}
\hline \multirow{3}{*}{ Countries } & \multicolumn{4}{|c|}{ FDI } & \multicolumn{5}{|c|}{ Export } \\
\hline & \multirow{2}{*}{$\begin{array}{l}\text { EMU } \\
\text { effect }\end{array}$} & \multicolumn{2}{|c|}{ Exchange rate } & \multirow[b]{2}{*}{ Total } & \multirow{2}{*}{$\begin{array}{l}\text { EMU } \\
\text { effect }\end{array}$} & \multicolumn{2}{|c|}{ Exchange rate } & \multirow{2}{*}{$\begin{array}{c}\text { Indirect } \\
\text { FDI } \\
\end{array}$} & \multirow[b]{2}{*}{ Total } \\
\hline & & Volatility & Change & & & $\mathrm{TB} * \mathrm{~V}$ & Change & & \\
\hline Сур & 21.17 & 0.03 & 2.41 & 23.61 & 6.93 & 0.02 & 0.19 & 0.48 & 7.62 \\
\hline Czech R. & 21.17 & 0.61 & -0.04 & 21 & 6.93 & -0.02 & 0.65 & 0.44 & 8.00 \\
\hline Estonia & 21.17 & 0.09 & 0.29 & 21.55 & 6.93 & 0.05 & 0.12 & 0.44 & 7.54 \\
\hline Hungary & 21.17 & 7.47 & 1.68 & 30.32 & 6.93 & -2.51 & 2.41 & 0.61 & 7.44 \\
\hline Latvia & 21.17 & 0.04 & -1.89 & 19.32 & 6.93 & -0.02 & 0.68 & 0.39 & 7.98 \\
\hline Lithuania & 21.17 & 0.02 & 1.11 & 22.30 & 6.93 & 0.00 & -6.55 & 0.45 & 0.83 \\
\hline Malta & 21.17 & 0.11 & -2.30 & 18.98 & 6.93 & 0.02 & 5.97 & 0.38 & 13.30 \\
\hline Poland & 21.17 & 0.28 & -2.95 & 18.50 & 6.93 & -0.04 & 3.46 & 0.37 & 10.72 \\
\hline Slovakia & 21.17 & 0.59 & 2.02 & 23.78 & 6.93 & 0.19 & 0.38 & 0.48 & 7.98 \\
\hline Slovenia & 21.17 & 1.19 & -0.79 & 21.57 & 6.93 & 0.37 & 0.13 & 0.44 & 7.87 \\
\hline
\end{tabular}

Notes: (a). All numbers are percentage changes with respect to the base scenario, that is, data obtained from the static simulation of estimated equations. We are considering a country by country enlargement; (b) For FDI the cells are obtained as follows: column EMU effect = setting EMU2 at 1; column volatility = volatility with third countries is now that of the euro and volatility with the euro is set at zero (as $\ln 0=-\infty$ we set estimated parameters of $\ln$ volatility and of $\mathrm{TB}^{*} \ln$ volatility equal to zero); column Change = setting exchange rate changes with the euro at zero; total= sum of all previous columns; (c) Likewise for exports except: column Indirect FDI = product of column (4) times elasticity of FDI in export equation.

Intuitively, the implementation of EMU for a candidate country means replacing a (managed) floating exchange rate regime by a common currency. Hence, a counterfactual scenario consists of bringing three major changes in our data. First, the true significance of the euro is obtained by setting the binary variable EMU2 to 1. It is important to note that EMU1(new) is not set to zero because this coefficient probably also captures transition effects on trade and

\footnotetext{
${ }^{10}$ Base scenario is the solution of our model before the change to EMU without carrying over the estimation residuals.
} 
investment. Second, volatility with third countries becomes that of the euro. Also the bilateral exchange rate volatility with the euro should be set to zero. However, as $\ln 0=-\infty$ it is similar to set the estimated parameters of $\ln$ volatility and of TB* $\ln$ volatility equal to zero. Third, the currency takes its central parity rate whereby exchange rate changes become null. For trade, a fourth effect is added which corresponds to the change in trade that is induced by its positive relationship with FDI.

Results in Table 9 are based on estimates of Table 5. The direct FDI effect of EMU in Table 9 can be approximated by $\left(e^{0.192}-1\right) * 100 \approx 21.17 \%{ }^{11}$ Whereas this effect is common to all potential entrants, cross-country variations in the results emerge from exchange rate movements in 2004. Since exchange rate volatility has a negative effect on FDI, bringing down to zero the exchange rate volatility with the euro has a positive effect on FDI. The larger the observed volatility in 2004 is the larger the potential gain of volatility reduction. This is definitely the case for Hungary that experienced the largest exchange rate volatility among the new ten EU members. Changes in the level of the exchange rates are differentiated in both sign and absolute value. The direct export effect of EMU is $\left(e^{0.067}-1\right) * 100 \approx 6.93 \%$ and is also common to all countries. Compared to FDI, other effects on trade differ in two respects. First, the volatility effect on trade depends also on the sign of the trade balance. Second, there is the induced effect of FDI on exports. In total, trade effects vary between $0.84 \%$ for Lithuania to $13.3 \%$ for Malta. Some of these effects arise from the complementarity with FDI. A reason for the unusually weak elasticity of FDI in the trade equation might be that most cross-country variations are picked up by the country-pair binary variables.

\section{Candidate Countries?}

Besides the importance of trade and foreign investment, membership to EMU would imply the loss of the macroeconomic flexibility of running an independent monetary policy. For that reason, candidate EMU countries have to satisfy Maastricht criteria in order to minimize the macroeconomic costs of a common monetary policy:

\footnotetext{
${ }^{11}$ In order to conduct a comparative static exercise, such as asking what the effects are of switching to a new exchange rate regime, three techniques are currently available to estimate the true effects of these institutional changes: a difference-in-differences approach, a general equilibrium analysis and a simulation-based analysis of a counterfactual scenario using mean estimates of a model. The multidimensional issues of EMU enlargement are too complex to be analyzed in a general equilibrium setting like in Anderson and van Wincoop (2003). In contrast true effects can be approximated using the counterfactual analysis that is more general than the difference-in-differences approach. As a matter of fact the difference-in-differences estimates of EMU are given by columns "EMU effect" of Table 9. These effects are common to all countries.
} 
- an inflation no more than 1.5 percentage points above the average of the three countries with the lowest inflation rates;

- nominal long-term interest rates not exceeding by more than 2 percentage points those of the three countries with the lowest inflation rates;

- no exchange rate realignment for at least two years;

- a gross debt to GDP ratio that does not exceed 60 percent;

- a government budget deficit not in excess of 3 percent of each country's GDP.

The first three criteria are designed to cover the loss of an independent monetary policy. The last two restrictions on government budgets are in place to protect the EMU from threats of inflation and to avoid the displacement of economic activity through fiscal policies. Though the last criterion has been broken recently by a number of current EMU members, it remains a tight constraint for potential entrants.

Table 10 Scores on Maastricht Criteria ${ }^{\mathrm{a}}$

\begin{tabular}{|c|c|c|c|c|c|c|}
\hline \multirow{2}{*}{ Countries } & $\begin{array}{c}\text { Inflation } \\
\text { (HICP) }\end{array}$ & $\begin{array}{c}\text { Budget } \\
\text { deficit to } \\
\text { GDP }\end{array}$ & $\begin{array}{l}\text { Government } \\
\text { debt to GDP }\end{array}$ & $\begin{array}{c}\text { Exchange } \\
\text { rate }\end{array}$ & $\begin{array}{c}\text { Long term } \\
\text { interest } \\
\text { rate }\end{array}$ & $\begin{array}{c}\text { Criteria } \\
\text { satisfied? }\end{array}$ \\
\hline & 2.9 & -3 & 60 & ERM2 $^{\text {b }}$ & 5.8 & yes/no \\
\hline Cyprus & 1.5 & -1.5 & 65.3 & + & 4.3 & no \\
\hline Czech Republic & 1.5 & -2.9 & 30.4 & - & 3.7 & no \\
\hline Estonia & 5.1 & 3.8 & 4.1 & + & 4.7 & no \\
\hline Hungary & 6.6 & -9.2 & 66.0 & - & 6.8 & no \\
\hline Latvia & 6.8 & 0.4 & 10.0 & + & 4.9 & no \\
\hline Lithuania & 6.0 & -0.3 & 18.2 & + & 4.3 & no \\
\hline Malta & 0.8 & -2.6 & 66.5 & + & 4.3 & no \\
\hline Poland & 1.4 & -3.9 & 47.8 & - & 5.1 & no \\
\hline Slovakia & 3.7 & -3.4 & 30.7 & + & 4.2 & no \\
\hline Slovenia & 3.0 & -1.4 & 27.8 & + & 3.9 & no \\
\hline
\end{tabular}

Notes: (a) Own compilations from Eurostat data (December 2006). Bold figures indicate when a given criterion is satisfied; (b) "+" in the column ERM2 indicates participation to ERM2; "-"no participation to ERM2. Participation means that a central parity rate against the euro is set for the currency and the currency may then fluctuate by a certain percentage relative to the central parity rate.

Table 10 shows how the 10 countries that joined the EU in 2004 performed on each of the five criteria. It is clear that none of the ten met the euro-adoption criteria at the end of December 2006. Though Cyprus, Czech Republic, Malta and Slovenia were strong performers, each failed to achieve one criterion in the table, sometimes by a small margin (like Slovenia that adopted the euro on Jan 1, 2007). In contrast, Hungary met none of the criteria. Other countries faced fiscal problems or had too high inflation rates. 
Regardless of Maastricht criteria, all countries of our analysis emerge as potential gainers in terms of foreign trade and investment. The reason is that besides the true significance of EMU exchange rates matter as well. We have shown that for most countries effects of exchange rate changes reinforce EMU effects. Therefore, based on our analysis, countries that almost meet Maastricht criteria (other than Slovenia) could be equally admitted to the EMU.

\section{Conclusion}

This paper has considered the nature and the distribution of trade and FDI effects of a potential enlargement of the European Monetary Union (EMU) to the ten countries that obtained EU membership in 2004. The above analysis provides evidence that EMU enlargement to the ten new EU countries can generate positive effects on the amount of FDI they are expected to receive. The evidence on trade is positive as well. Some of the trade effects arise from higher FDI stocks as our empirical results support the hypothesis of a positive correlation between trade and FDI.

Our framework includes some specific assumptions and, though numerous checks were performed, results are still subject to the issue of robustness. First, in order to conduct a comparative static exercise, such as asking what the effects are of switching to a new exchange rate regime, one should solve a general equilibrium model before and after the change. Since our analysis ignores price and income effects of EMU enlargement it is an approximation of its true effects. However, as income is supposed to rise and inflationary expectations to decrease with EMU, our results could be interpreted as lower bounds. Second, the numerous cells with zeroes in our panel data caused problems in the estimation of our models. Though this is an old issue in gravity models of trade, for which solutions are now available (see e.g. Helpman et al., 2007), the new difficulty lied in the FDI data. Zero reported stocks could point out measurement problems or high setup costs of new foreign investment (see e.g. Razin et al., 2004). Our solution was to exclude observations that were lower than a specific bound but other methods could be explored. Third, our empirical analysis had difficulties in distinguishing between the true effects of the early introduction of the euro and those resulting from the transition from closed to open economies. The ten new EU members are still in an evolution phase and our estimated coefficients probably capture this changeover. More empirical work should be able to clarify the relative contribution of each. However, it is hoped that the analysis presented here offers a convenient framework within which further research on such issues can be conducted. 


\section{References}

Anderson, J. (1979), "A Theoretical Foundation for the Gravity Equation," American Economic Review, 69, 106-116.

Anderson, J. and E. van Wincoop (2003), "Gravity with Gravitas: A Solution to the Border Puzzle," American Economic Review, 93, 170-192.

Baier, S.L. and J.L. Bergstrand (2007), "Do Free Trade Agreements Actually Increase Members' International Trade?” Journal of International Economics, 71(1), 72-95.

Baldwin, R. (2006), “The Euro’s Trade Effects,” ECB Working Paper, 549.

Baltagi, B.H., P. Egger, and M. Pfaffermayr (2003), "A Generalized Design for Bilateral Trade Flow Models,” Economics Letters, 80(3), 391-397.

Baltagi, B.H. (2005), Econometric Analysis of Panel Data, (Chichester: John Wiley and Sons), $3^{\text {rd }}$ Edition.

Bergstrand, J.H. (1989), "The Generalized Gravity Equation, Monopolistic Competition, and the Factor-Proportions Theory in International Trade," Review of Economics and Statistics, 71(1), 143-153.

Blonigen, B., R.B. Davies, and K. Head (2003), "Estimating the Knowledge-Capital Model of the Multinational Enterprise: Comment," American Economic Review, 93, 980-994.

Bowen, H., A. Hollander, and J. M. Viaene (1998), Applied International Trade Analysis, (Ann Arbor: University of Michigan Press).

Brenton, P., F. Di Mauro, and M. Lücke (1999),"Economic Integration and FDI: An Empirical Analysis of Foreign Investment in the EU and in Central and Eastern Europe," Empirica, 95-121.

Broll, U. and I. Zilcha (1992), "Exchange Rate Uncertainty, Futures Markets and the Multinational Firm," European Economic Review, 36(4), 815-826.

Carr, L., R. Markusen, and E. Maskus (2001), "Estimating the Knowledge-Capital Model of the Multinational Enterprise," American Economic Review, 91, 693-708.

Coes, D. (1981), “The Crawling Peg and Exchange Rate Uncertainty," in Williamson, J. (ed.), Exchange Rate Rules: The Theory, Performance and Prospects of the Crawling Peg (New York: St. Martin's Press), 113-136.

De Sousa, J. and J. Lochard (2006), "Does the Single Currency affect FDI? A Gravity-like Approach," Working Paper, University of Paris and University of Rennes.

Deardorff, A. (1995), "Determinants of Bilateral Trade: Does Gravity Work in a Neoclassical World?" Working Paper, The University of Michigan.

Dixit, A. (1992),'Investment and Hysteresis," Journal of Economic Perspectives, 6(1), 107132.

Eldor, R. and I. Zilcha (1991), "Exporting Firm and Forward Markets: The Multi-period 
Case," Journal of International Money and Finance, 10, 108-117.

Feenstra, R.E. (2002), "Border Effects and the Gravity Equation: Consistent Methods for Estimation," Scottish Journal of Political Economy, 49, 491-506.

Flam, H. and H. Nordström (2003), "The Trade Volume Effects of the Euro: Aggregate and Sector Estimates," Institute for International Economic Studies, Working Paper 746.

Froot, K. and J.C. Stein (1991), "Exchange Rates and Foreign Direct Investment: An Imperfect Capital Markets Approach," Quarterly Journal of Economics, 106, 1191-1217.

Helpman, E. and P. Krugman (1985), Market Structure and Foreign Trade, (Cambridge: MIT Press).

Helpman, E., M. Melitz and Y. Rubinstein (2007), "Estimating Trade Flows: Trading Partners and Trading Volumes," NBER Working Paper 12927.

Klaassen, F. (2004), "Why is it so Difficult to find an Effect of Exchange Rate Risk on Trade?" Journal of International Money and Finance, 28, 817-839.

Markusen, J.R. (1983), "Factor Movements and Commodity Trade as Complements," Journal of International Economics, 14, 341-356.

Martin, P. and H. Rey (2004), "Financial Super-markets: Size Matters for Asset Trade," Journal of International Economics, 64, 335-361.

Micco, A., E. Stein, and G. Ordonez (2003), "The Currency Union Effect on Trade: Early Evidence from EMU," Economic Policy, 18, 315-356.

Mundell, R. (1957), "International Trade and Factor Mobility," American Economic Review, 47, 321-335.

Petroulas, P. (2007), "The Effect of the Euro on Foreign Direct Investment," European Economic Review, 51(6), 1468-1491.

Portes, R. and H. Rey (2005), "The Determinants of Cross-border Equity Flows," Journal of International Economics, 65, 269-296.

Razin, A., Y. Rubinstein, and E. Sadka (2004), "Fixed Costs and FDI: The Conflicting Effects of Productivity Shocks,“,” NBER Working Paper 10864.

Rose, A. (2000), "One Money, One Market: Estimating the Effect of Common Currencies on Trade," Economic Policy, 30, 9-45.

Rose, A. (2004), "A Meta-analysis of the Effect of Common Currencies on International Trade,” NBER Working Paper 10373.

Roy, S. and J.-M. Viaene, (1998), “On Strategic Vertical Foreign Direct Investment,” Journal of International Economics, 46(2), 253-279.

UNCTAD (1993), World Investment Report 1993, (Geneva: UNCTAD).

UNCTAD (2006), World Investment Report 2006: FDI from Developing and Transition Economies, (Geneva: UNCTAD). 
Viaene, J.-M. and C. de Vries (1992), "International Trade and Exchange Rate Volatility," European Economic Review, 36, 1311-1321.

Wong, K.-Y. (1988), "International Factor Mobility and the Volume of Trade: An Empirical Study," in Feenstra, R.C.(ed.), Empirical Methods for International Trade (Cambridge: MIT Press), 231-250.

\section{Appendix}

\section{A. Data Sources and Methods}

Unilateral data on export are obtained from the Direction of Trade Statistics (DOTS) published by the International Monetary Fund (IMF). Annual averages of FOB exports are used for the period 1980-2005. The values are measured in United States dollars (US \$); conversion to US $\$$ is done by using year to year exchange rates.

FDI data are taken from the International Direct Investment by Country Table (2005, release 01), which has been put together by the Organization for Economic Co-operation and Development (OECD). The data set contains annual averages of the outward FDI stock for the period 1990-2004. The values are measured in US \$.

The real exchange rates are taken from the IMF's International Financial Statistics. Monthly averages are used for the period 1980.01 until 2006.11. Changes are expressed in percentage changes.

The gravity variables, distance, contiguity, and language, are taken from Centre d'Etudes Prospectives et d'Informations Internationales (www.cepii.fr).

Nominal GDP is obtained from the IMF, International Financial Statistics.

The country groupings are as follows. EMU = Austria, Belgium, France, Finland, Germany, Greece, Ireland, Italy, Luxembourg, The Netherlands, Portugal and Spain. Year of EMU entry for these countries is 1999, except for Greece that joined in 2001; NEW= Estonia, Hungary, Slovenia, Malta, Cyprus, Poland, Czech Republic, Latvia, Lithuania and Slovakia. These countries joined the EU in 2004; RU = Denmark, Sweden, U.K.; RW = Canada, Japan, Switzerland and U.S. The EU consists of 25 countries, all countries in our sample except RW. Year of EU entry for Austria, Finland and Sweden is 1995. 


\section{B. Least Square Estimates with Deflated Variables}

For the sake of comparison Table 11 gives the results of estimation in real terms. The specification is similar to that of Table 2 . The difference is in the definition of variables: $X_{i j}$, $\mathrm{GDP}_{i}$ and $\mathrm{FDI}_{i j}$ are deflated by the GDP deflator of country $i$; $\mathrm{GDP}_{j}$ by the GDP deflator of country $j$. From Tables 2 and 11 it is clear that signs and estimates of key variables are comparable.

Table 11 Country Fixed Effects with Deflated Variables

\begin{tabular}{|c|c|c|c|c|}
\hline \multirow{3}{*}{$\begin{array}{l}\text { Explanatory } \\
\text { Variables }\end{array}$} & \multicolumn{4}{|c|}{ Equation (1) } \\
\hline & \multicolumn{2}{|c|}{ ln export } & \multicolumn{2}{|c|}{$\ln$ FDI } \\
\hline & (1) & (2) & (3) & (4) \\
\hline $\ln \mathrm{GDP}_{\mathrm{i}}$ & $0.591(0.000)$ & & $1.573(0.000)$ & \\
\hline $\ln \mathrm{GDP}_{\mathrm{j}}$ & $0.311(0.000)$ & & $2.030(0.000)$ & \\
\hline In distance & $-0.717(0.000)$ & $-0.691(0.000)$ & $-0.961(0.000)$ & $-0.908(0.000)$ \\
\hline contiguity & $0.399(0.000)$ & $0.401(0.000)$ & $0.276(0.004)$ & $0.330(0.001)$ \\
\hline language & $0.216(0.000)$ & $0.208(0.000)$ & $0.338(0.001)$ & $0.336(0.001)$ \\
\hline $\ln \mathrm{FDI}$ & $0.155(0.000)$ & $0.174(0.000)$ & & \\
\hline TB* ln volatility & $-0.086(0.010)$ & $-0.084(0.000)$ & & \\
\hline ln volatility & & & $0.111(0.003)$ & $0.083(0.037)$ \\
\hline XR change & $-0.026(0.010)$ & $-0.013(0.217)$ & & \\
\hline XR appreciation & & & $0.043(0.252)$ & $0.049(0.219)$ \\
\hline XR depreciation & & & $-0.050(0.258)$ & $-0.052(0.262)$ \\
\hline EU2 & $0.094(0.027)$ & $0.193(0.000)$ & $0.424(0.000)$ & $0.927(0.000)$ \\
\hline EU1 & $-0.064(0.160)$ & $0.011(0.807)$ & $-0.089(0.484)$ & $0.280(0.036)$ \\
\hline EMU2 & $0.063(0.062)$ & $0.157(0.000)$ & $0.565(0.000)$ & $1.030(0.000)$ \\
\hline EMU1(new) & $0.108(0.013)$ & $0.245(0.000)$ & $0.230(0.051)$ & $1.023(0.000)$ \\
\hline EMU1(ru) & $0.044(0.396)$ & $0.138(0.008)$ & $0.379(0.008)$ & $0.798(0.000)$ \\
\hline EMU1(rw) & $-0.038(0.409)$ & $0.060(0.185)$ & $0.241(0.073)$ & $0.669(0.000)$ \\
\hline $\bar{R}^{2}$ (adjusted) & 0.924 & 0.921 & 0.756 & 0.727 \\
\hline $\bar{R}^{2}$ (adj, within) & 0.699 & 0.691 & 0.333 & 0.255 \\
\hline
\end{tabular}

Notes: (i) panel least squares with country pair dummies; (ii) p-values in parentheses; (iii) No. of observations in columns (1) and (2) $=4152$; (iv) No. of observations in columns (3) and (4) $=3542$, as we impose FDI $>0.01$; (v) within $\bar{R}^{2}$ is computed on demeaned data. 